\title{
走查電子題微鏡によるヒト䫑関節円板の研究
}

一七ト正常関節円板の 3 次元的構筑——

小沢匪焳

\section{Scanning electron microscopic study of human articular disc of the temporomandibular joint}

-Three-dimentional architecture of human normal disc-

\author{
Shigeo Ozawa
}

緒

言

顎関節円板は下顎頭と下顎窩・関節結節との間に介在 し, 両者を適合維持するとともに, 蝶番ならびに滑走両 運動を営んで関節單動に関与し，またショックアブゾー パーとしての働きをるつなと，顎関節構成組織のなかで も生理学的にきわめて重要な組織であると考えられる。 したがって，さまざまな器械的負荷を蒙りやすく，それ

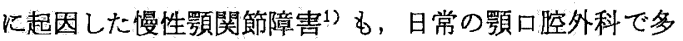
く経験するところであり，臨床病理学的意義も大きい.

顎関節円板は，打もに膠原線維からなる円盤状を呈す る組織であるが，その組織学的研究 2 15) は少なくいまだ 詳細は明らかにされていない。

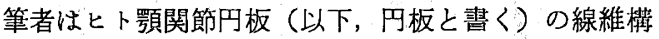
築を明らかにするため, 走査電子顕微鏡（以下，走查電 顕と書く)によって円板表面盽造を観察し, 若千の知見 を得たので報告する。

\section{研 究 試 料}

臨床上, 健常と思われる 5 例 5 円板を研究の試料にし た。表 1 に示すよ 5 に，4 例 4 円板は下顎関節離断術の 扣りに，1例 1 円板は剖検例（舌腫瘍症例）からそれぞ れ得たものである。

\section{研 究 方 法}

図1に示すように，採取した円板をたたぢ生理食塩

埼玉医科大学口腔外科学教室

（主任：高久 暹教授）

Department of Oral Surgery, Saitama Medical

School (Chief: Prof. Susumu Takaku)

受付日：昭和 58 年 7 月 25 日
表 1 研究試料

\begin{tabular}{|c|c|c|c|}
\hline 年粒 & 性別 & 病名 & 試 料 採 取 \\
\hline 76 & 男 & 下顎骨腫湟 & 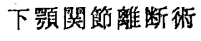 \\
\hline 34 & 男 & 下顎骨嗹湶 & 下顎関節離断術 \\
\hline 20 & 男 & 下顎骨腫曒 & 下顎風節雄断術 \\
\hline 25 & 男 & 下顎骨腫瘍 & 下買関節離断術 \\
\hline 57 & 男 & 舌 腫 漡 & 檢 \\
\hline
\end{tabular}

水でよく洗浄し， $2.5 \%$ グルールアルデヒド溶夜（0.1 Mリン酸緩衙液， $\mathrm{pH}$ 7.4) で前固定した。 ついで図 2 に示すように, 両刃安全カミソリの刃によって, 円板の ほほ中央で矢状切断と前額切断を行ったが，さらに， それぞれの凍結破断面を観察する目的で, 隣接する部分 から約 $4 \times 3 \mathrm{~mm}$ の小片を 3 ないし 4 個切り出しておい た.これら小片として切り出した円板を緩衙液 $(0.1 \mathrm{M}$ リン酸緩衝液）で洗浄したのち，1\%四酸化オスミウム 溶液 (0.1 Mリン酸緩衝液) で二重固定し, ついで上昇 エタノールで脱水し, 酢酸イソアミル中に浸漬した。な お，破断面の钼察を目的とした小片（約 $4 \times 3 \mathrm{~mm}$ ) は, 脱水の最終過程である無水エタノール中でゼラチンカプ セルに封入して, 液体窒素で倲結したのち破断した。破 断後, 無水エタノール中にもどし, 矢状切断, 前額切断 の各試料と同様に酢酸イソアミル中に浸漬した。そし て, 括の括のの小片を臨界点乾燥装置 (日立 HCP-1 形, HCP-2 形) で乾燥を行った後，イオンスパッタリング 装置（エイコーエンジニアリング MULTI・COATER VX-10 A) で，白金ーパラジウムの蒸着を行い，日立明 石走査電子顕微鏡 MSM-7 C と日立走査電子顕 微 鏡 S・550で倠察した。

\section{成 績}

1. 表面および矢状切断面構造

写真 1 は, 円板前方周縁の表面と切断面を示すが, 表 


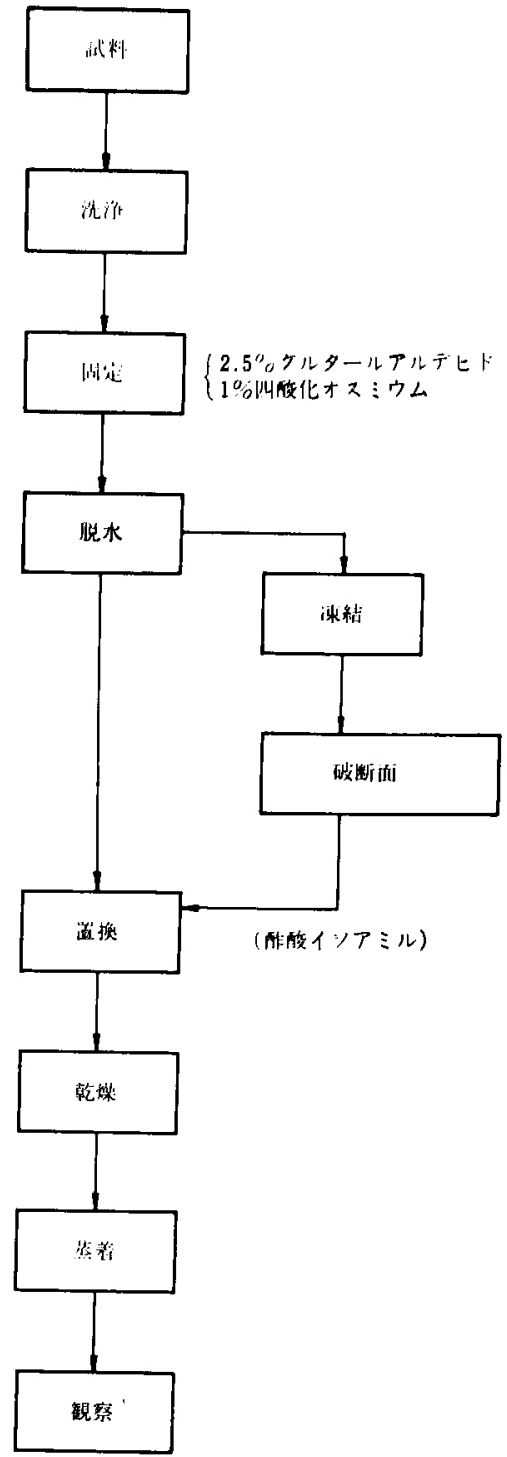

図 1 研究方法

面のとダ状構造の内層が明嘹である。ヒダ状棈造は，幅 約 5 12 $\mu \mathrm{m}$, 振幅約 3 10 $\mu \mathrm{m}$ の隆起で切断面に対し て直交している。しかしながら，切断面から隔たるにし たがって，上ダ状箱造の走行は写真1に示すよ5に，右 上方向に向かって湾曲している，それについては，七ダ 状構浩が円板周縁に沿って走行している一部を矢状切断 したためである。しかしながらこのヒダ状椣造は一つ 一つが独立して円板周縁に沿って走行するのではなく， 隆起は隣接する隆起と相交わって1つになり，1つの隆 起は分離して 2 つ隆起になる。このよらな隆起のくり かえしにより，全体としてヒダ状構造は円板周椂に沿っ

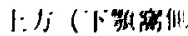

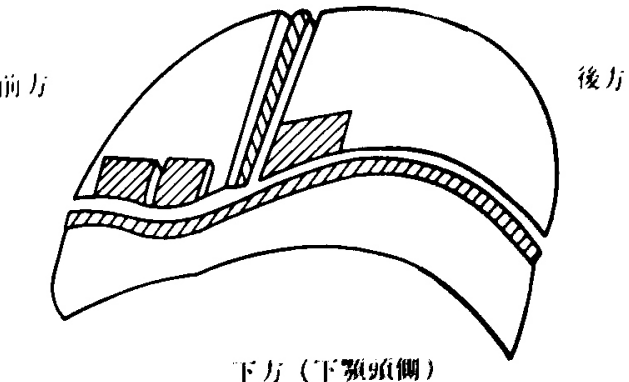

因 2 策蛅位

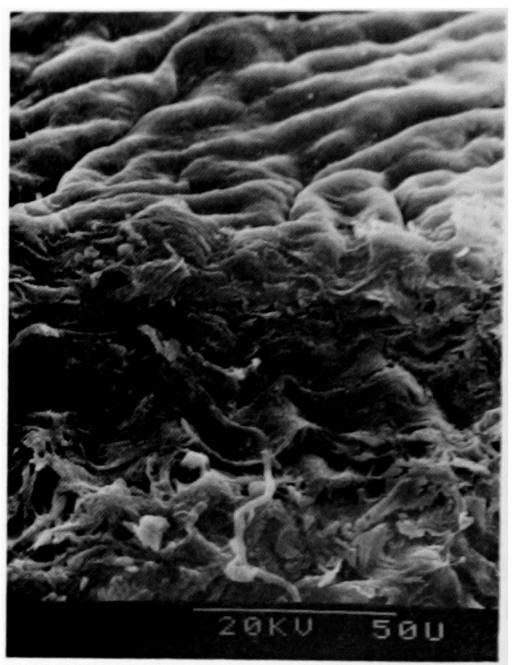

写重 1 表面お上ひ矢状切断面像

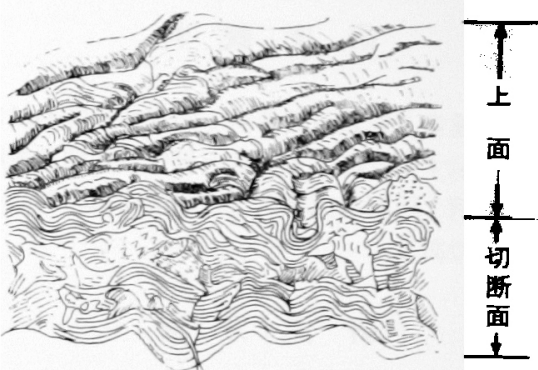

図了表面および矢状切断面模式图

て走行する。

ヒダ状構造は，その走行にほぼ直交して走行する多数 の膠原線維からなって扣り，切断面からみると，直線的 ではなく，波形をなして走行している．模式図的に示す ならば、図了のよらになる。 


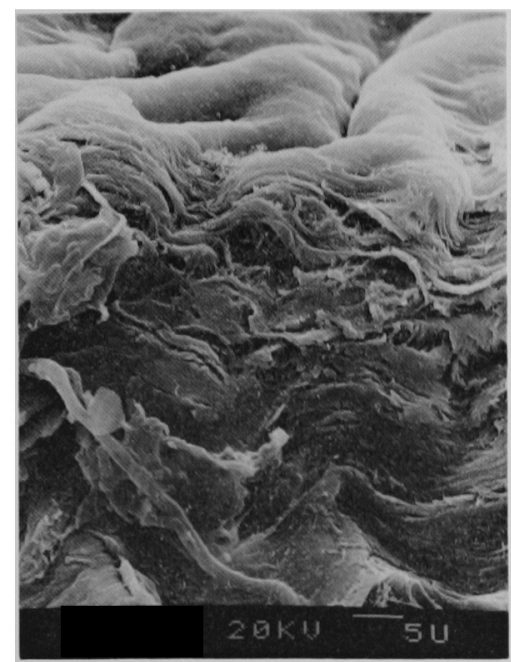

写真 2 写真 1 の抎大像

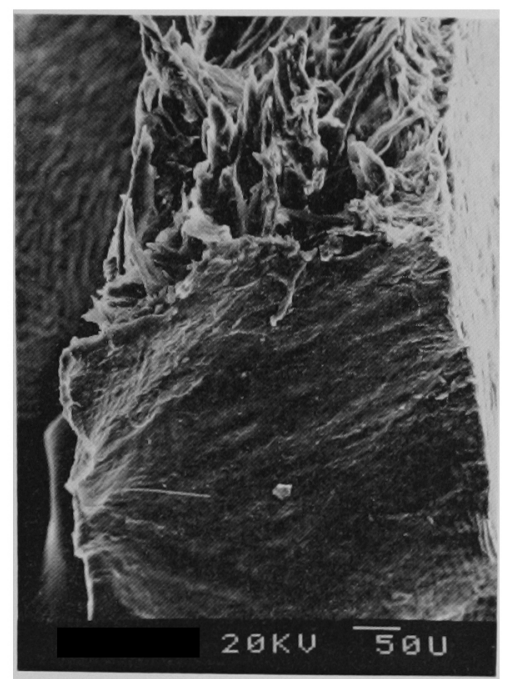

写真 3 表面扣上び矢状破断面 上方が破断面，下方が円板 表面.

強厸大(写真 2 )によると、ヒダ状棈造の最表層部は, 厚さ 4 7 $\mu \mathrm{m}$ 程度の密な線維層で，それを棈成する線維 は直線的ではなく，波形をなして走行している。

\section{2. 表面構造と矢状破断面}

写直了は，円板表面と知状方向に凍結破断した面を， 的45度の角度から観察した像である.円板表面には，約 $25 \mu \mathrm{m}$ の大きな波形構造と幅 6〜7 $\mu \mathrm{m}$ の小さなとダ状 構造が認められる。ヒダ状構造は前述と同様の線維構築 からなっているが，その最表層直下の線維楧築は，表層 とは異にし，表面に対して直交するるの，斜走するる

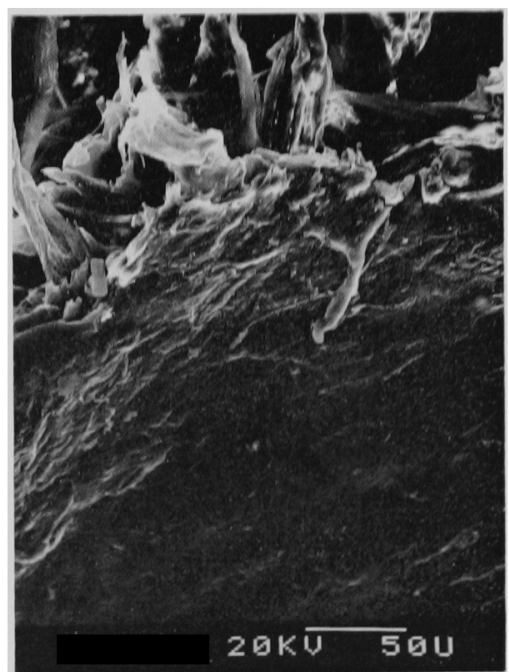

写真 4 写真 3 の扗大像

上方（下频窝僋）

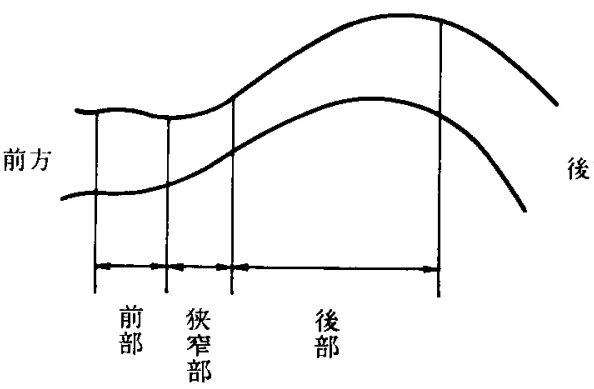

図4 円板矢状切断面からみた唒察部位

のまたは走行方向の判断のしがたい線維束の交錯から なっている.

写直 4 は写真 3 の強扗大像であるが，最表層を除く と, 円板内部の線維排筑はきわめて複雑である。

\section{3. 正中矢状切断面椿造}

円板の正中矢状切断面の観察にあたって，筆者は図 4 に示すよらに，前部，狭窄部，後部の三つにまず区分 し，それぞれを円板の上面から下面へ，上層，中層，下 層に分けて観察した。 また円板後部結合組織（Rees の 二㬝部）についても観察した。

i ) 前 部

弱执大（写真 5 ）で観察すると，上層と下層はとすに 層板状にみえる.その厚さはそれぞれ的 $250 \sim 300 \mu \mathrm{m}$ ， $90 \sim 130 \mu \mathrm{m}$ 程度である。層は円板知状切断面の大部 分を占めて拈り，前述の上下耐層によって㣣まれている よ5にみえる.中層の線維楧築は円板表面に対して, おも に斜めに，あるいは平行に走行する線維束(あるいは束 


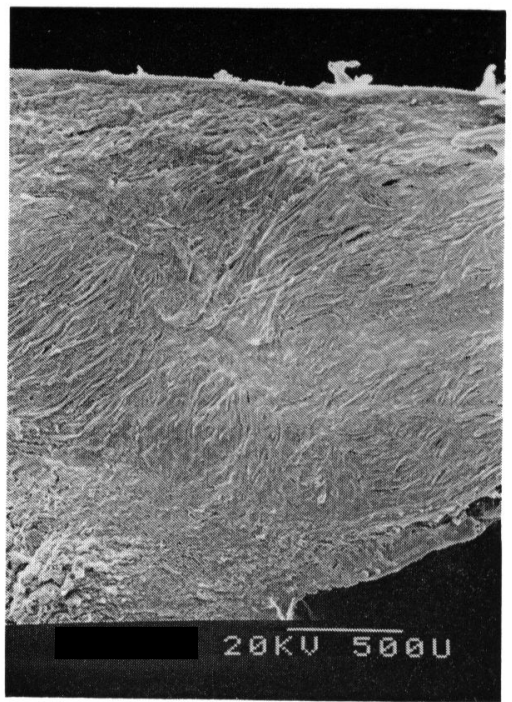

写真 5 円板前部矢状切断面

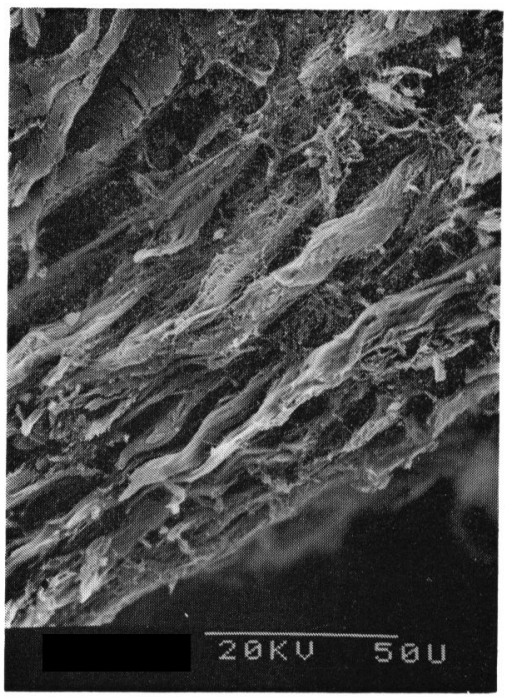

写真 6 円板前部下層拡大像

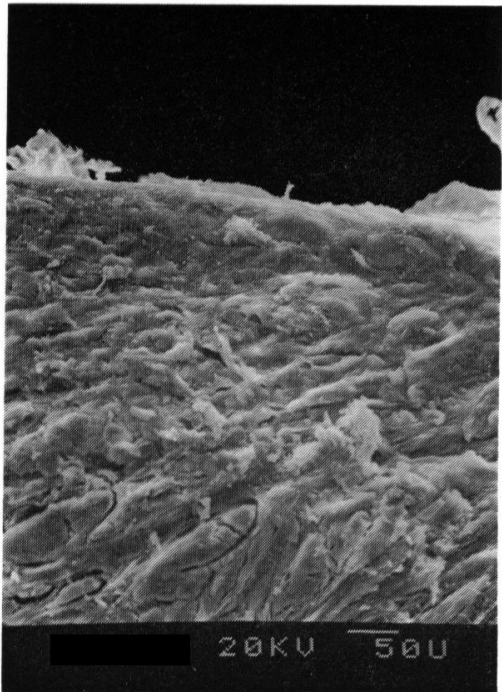

写真 7 円板前部上層拡大像

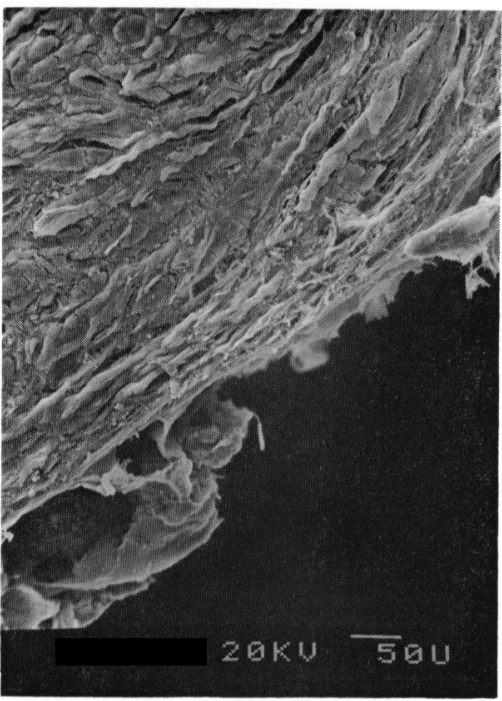

写真 8 円板前部下層拡大像
群）と，ほ注垂直に走行する線維束（あるいは束群）と の密な交錯からなり, その構築はきわめて複雑である。

上下両層は弱拡大で層板状にみ壳るが，強拡大（写真 6) では，扣もに波形をなして前後的に走行する線維束 （波形の周期，約 $5 \mu \mathrm{m}$ ) あるいは束群によって構成さ れ，ところどころには斜めあるいは矢状切断面に垂直に 走行する線維束（あるいは束群）もみられる。乙かし， 上面と下面に垂直に走行する線維束は認められない。な 扣, 上層と下層から中層へ移行するに従って, 線維構築 は複雑になっている。上下両層の線維構築を比較すると 扣扣むね似ているが，下層は上層に比べて線維束群を形
成している線維束の数は少ないが，その交錯はより密で ある(写真 7, 8).

中層（写真 9) では, 線維束とその集簇からなる大小 さまざまな線維束群からなるのがより明膫である。線維 束 (あるいは束群) の走行はいずれも複雑で, 直線的 に, 斜めに, あるいは波形（周期15～50 $\mu \mathrm{m}$ ）をなして 走行している。結果的に個々の線維束（あるいは束群） の走行は決めがたく, 多方向性で, さらにそれらは複雑 に交錯している。正中矢状断面構造を模式図的に示すな らば図5のよらになる。 


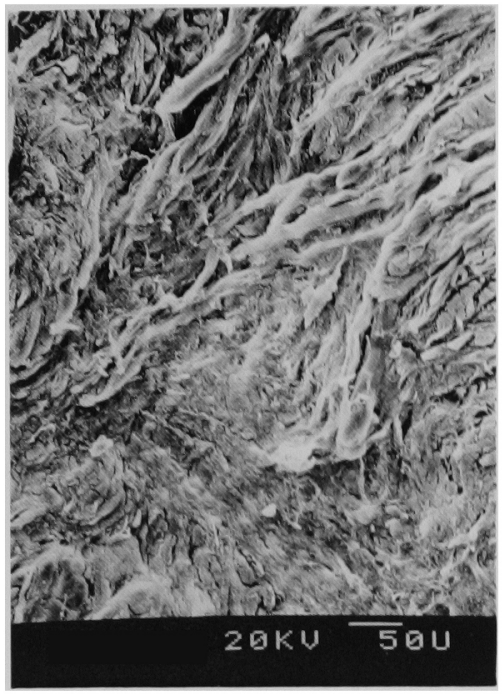

写真 9 円板前部中層执大像

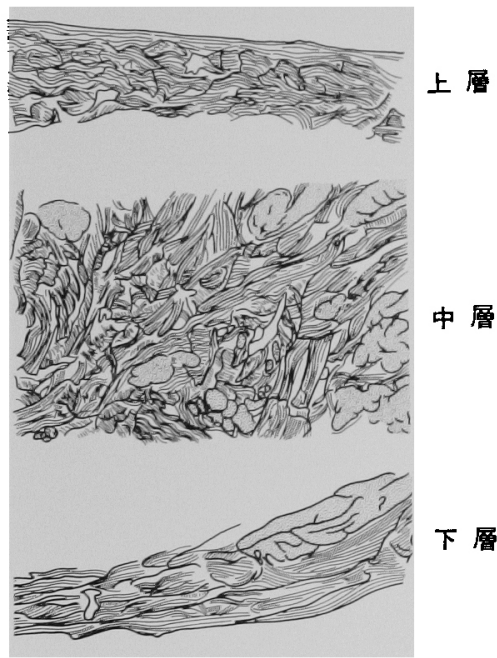

図 5 関節円板前部線維構築

ii) 狭窄部

弱抎大では，上下各層はいずれも層板状で，密に線維 が配列している，中層の構築は複雑ではなく，とくに上 面または下面に対して垂直に走行する線維束（あるいは 束群) は認められない(写真10).

弱抁大像で層板状にみ方る上層は，周期 5 15 $\mu \mathrm{m}$ 程 度（写真11）の波形を呈して，打もに前後方向に走行可 る線維束（あるいは束群）からなっているが，わずかに 矢状切断面に対して斜めに走行する線維束（あるいは束 群）も認められる。

中層む，和るに前後方向に走行する線維束（あるいは

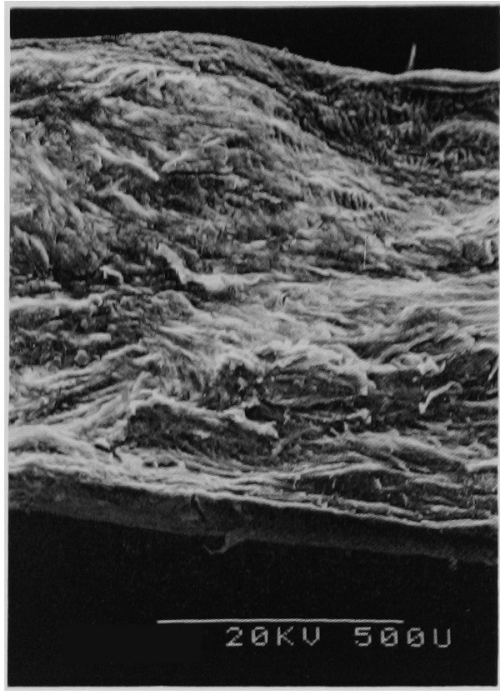

军 10 円板狭害部

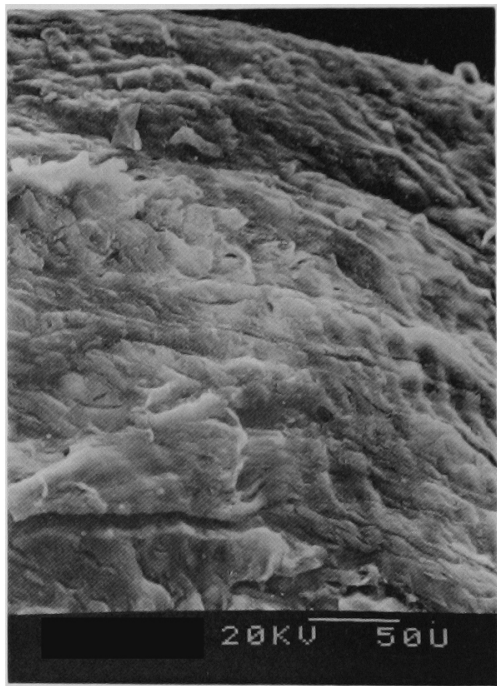

写直 11 円板狭窄部上啳摸大像

束群）からなっているが，並列する線維束（あるいは束 群）は捂いに入り組んでおり，さながら系の束をよっ たようにみえる。をた同部では，矢状切断面または上下 各面に対してそれぞれ垂直に，あるいは斜めに走行する 線維束（あるいは束群）は少ない(写真12).

下層は弱拡大で層板状にみえるが，上層に比へて線維 棈築を異にしている。扣すに矢状切断面または下面に対 してやや斜めになって走行する線維束（あるいは束群） と，前後方向に走行する楾維束（あるいは束群）之の交 錯からなる，また線維束群を構成する線維束の数は，上 層に比べて少ない（写真13）。な和下面に垂直に走行す 


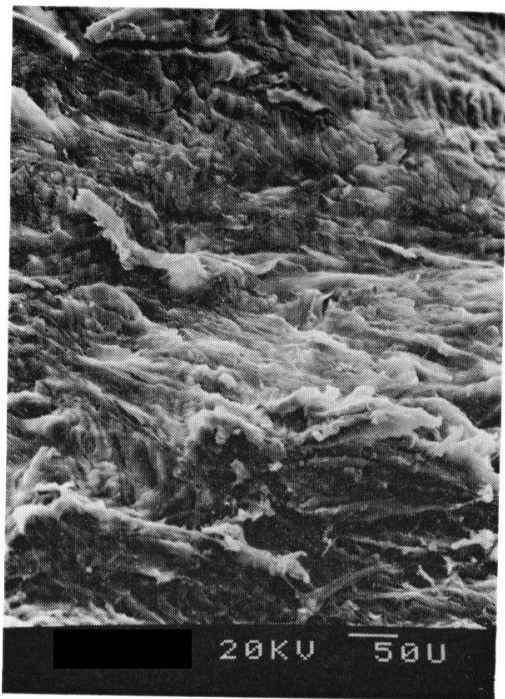

写真 12 円板狭窄部中層桩大像

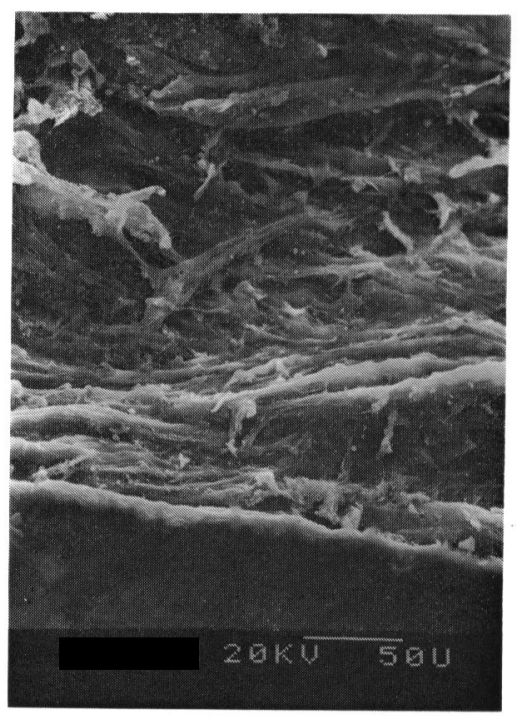

写真 13 円板狭窄部下層拡大像

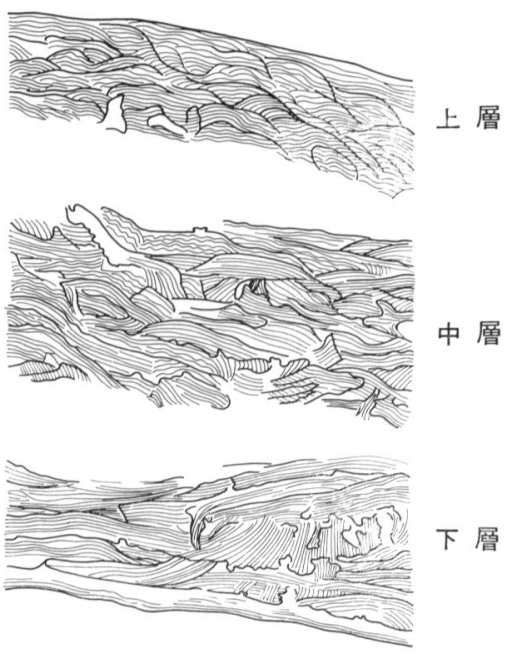

図 6 関節円板狭窄部線維構築

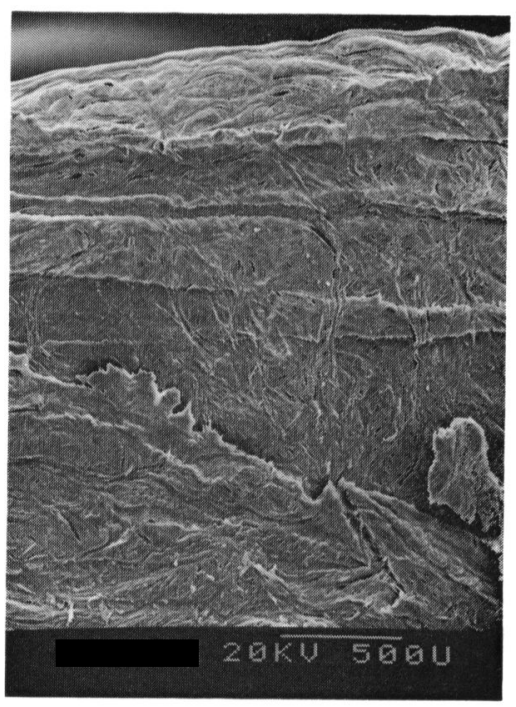

写真 14 円板後部
る線維束は認められない。正中矢状断面構造を模式図的 に示すならば図6のよらになる。

iii) 後 部

上層は，ゆるやかな波形をなして走行する線維束（あ るいは束群）からなる。波形の幅は約 160～300 $\mu \mathrm{m}$ 程 度で, 前部执よび狭窄部の上層構築のそれと比較すると 大きい(写真14).

強抎大像（写真15）によれば, 上層の厚さは 90 220 $\mu \mathrm{m}$ 程度であり, 線維束群を構成している線維束と, そ れを構成している線維も密になって蛇行して走行してい る。線維束は隣接する線維束または線維束群と入り組ん
でいるが，円板表面に対して垂直に走行する線維束はな い, 総じて，上層は層板状を呈している。

中層では, 大小の円形, 卵円形, 紡錘形などの形に切 断された線維束群の断面が随所に認められる。それら線 維束群切断面の間を, 円板の上面あるいは下面に対して 垂直に, 斜めに, またはほぼ平行に蛇行しながら走行す る線維束や線維束群が認められる。写真16では, 円形, 卵円形，紡錐形などに切断された線維束群の構造が明瞭 である。それは多数の走行方向を異にする線維束群の集 まったものであることを示す。また矢状断面に垂直に走 行する線維束（あるいは束群）の間を, 円板表面に対し 


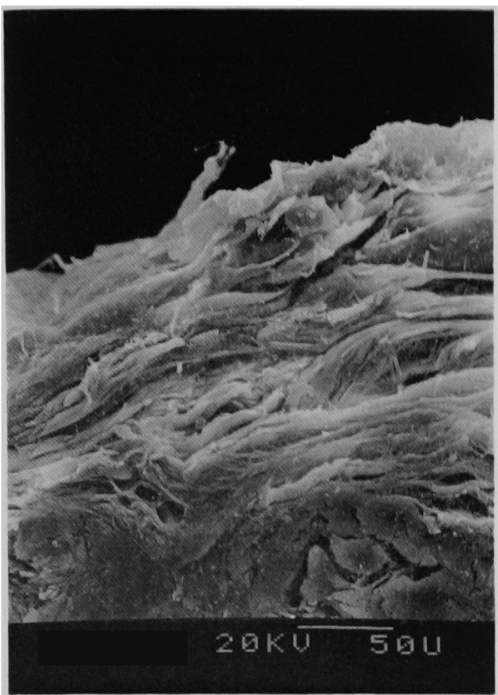

写直 15 円板後部上層扰大像

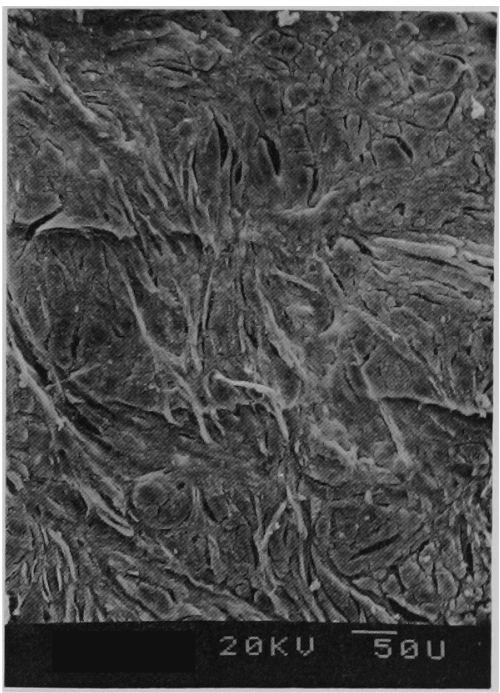

写真 16 円板後部中層抾大像

て垂直に，斜めに，または前後に蛇行して走行している 楾維束（あるいは束群）も認められる。

下層も上層と同様に，厚さ $60 \sim 90 \mu \mathrm{m}$ 程度の層板状 構造を形成し, 中層部の線維束 (あるいは束群) を包ん でいるようにみえる（写真 17），写真 18は，写真17の強 拡大像であるが，層板状構造は上層のそれに類似してい るが，隣接する線維束（あるいは束群）との入り組みは より密であり，強鞄な楧築を呈している，なお，円板下 面に対して，垂直に走行する線維束は認められない，正 中矢状断面構造を模式図的に示すならば图 7 のよ5にな る。

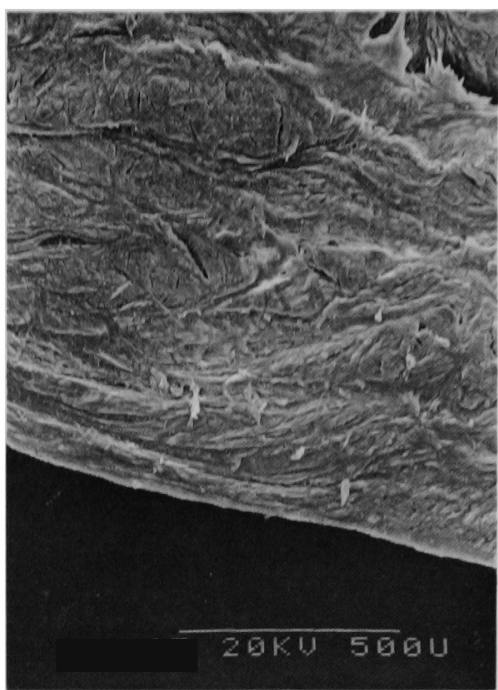

写王 17 円板後部下阊

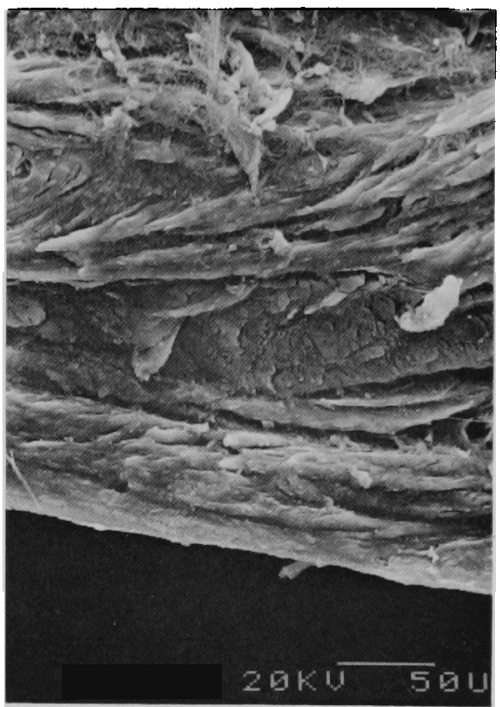

写真 18 写真17の执大像

iv) 円板後部結合組織

写真19に示すよらに，線維束の走行は一様で，円板後 部と後部結合組織との移行部は明らかに区別することは できない，線維束が後方に向かって密に波形をなして走 行するが，関節包付着部付近（写真19，右下）では線維 束は疎になっている，ところところに血管も認められ る。

4. 前額切断面構造

円板の前額切断面の観察にあたっては，図 8 に示すよ らに，円板中央部と周辺部に区分して観察した。 


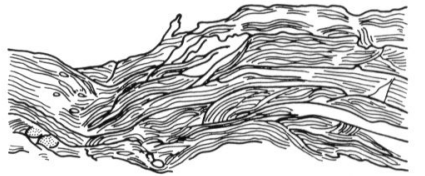

上 層
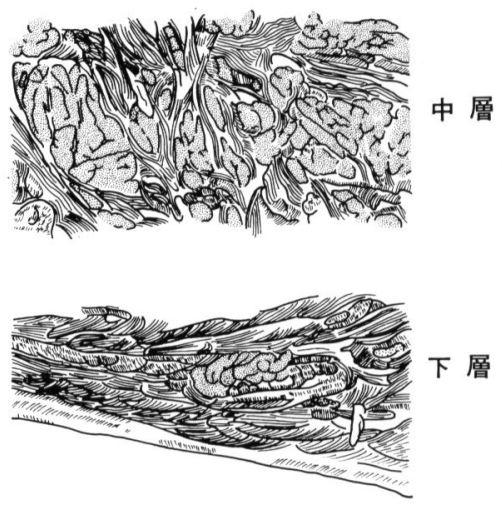

図 7 関節円板後部線䧽構築

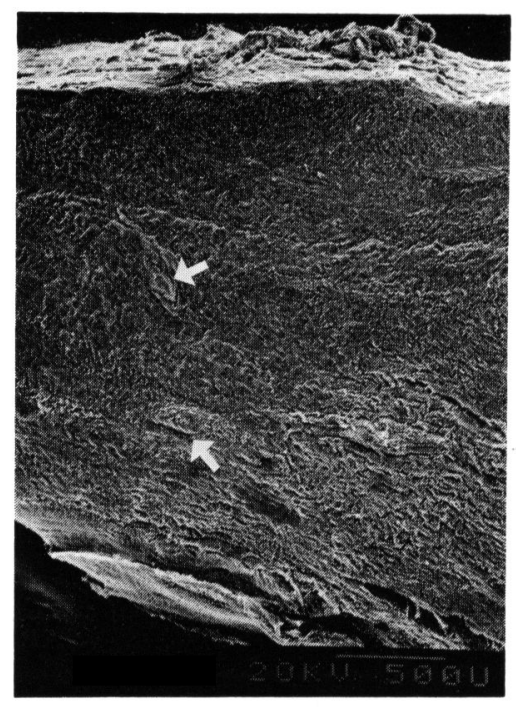

写真 19 円板後部結合組織 （矢印，血管老示す）

\section{i ）円板中央部}

上層の厚さは $90 \sim 160 \mu \mathrm{m}$ 程度で，密な線維束（ある いは束群）からなるため, 弱拡大（写真20）では層板状 にみ觉る，表層直下では，ところどころに小さい線維束 群の横断面が認められる。そ饥ら断面は多数の線維束の 集簇からなるが，これら上層付近の所見は，矢状断面か らの観察で，円板上面にほぼ平行になって，前後方向に 走行する線維束（あるいは束群）の断面像に相当する。

中層では, 円形, 卵円形をたは紡錘形に切断された大
上方（下顎窩側）

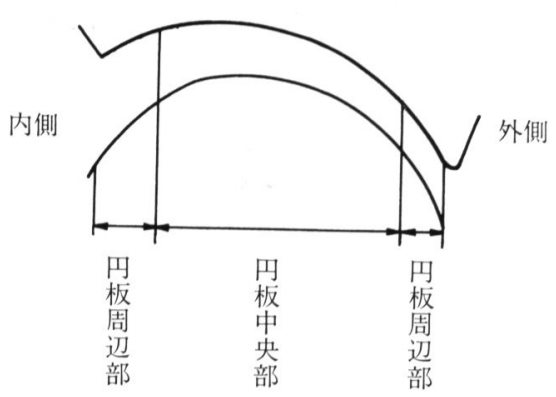

図 8 円板前額断からみた観察部位

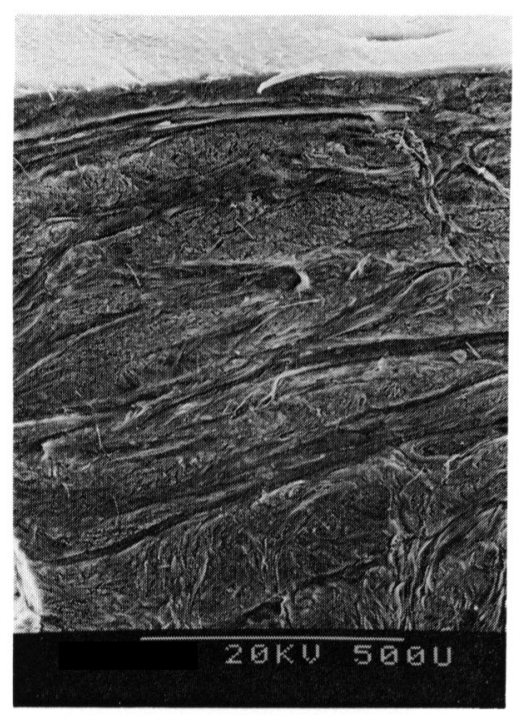

写真 20 円板中央部前額切断像

きな線維束群の断面を随所にみるが，その各断面間を満 たすように, 幅約 10～100 $\mu \mathrm{m}$ 程度の大小の線維束（あ るいは束群）が斜めに, 横に, あるいは上層に対して垂 直に走行しており，きわめて強勒な構築を呈している (写真21).

下層は, 層板状で厚さは $80 \sim 110 \mu \mathrm{m}$ 程度である。 上 層とほ湆同様の線維構築からなる（写真22）。

ii ) 円板周辺部

上層, 下層はともに中層部と区別しがたく, 線維束の 走行は多方向性で, 蛇行し, 複雑に交錯しているが, 線 維束間は疎である。また，血管がところどころに認めら れる（写真23），血管部を拡大寸ると血管内に血球が明 瞭である(写真24).

\section{5. 水平破断面構造}

i ) 前部から狭窄部への移行部付近

線維束は前後, 内外側およびそれらに対して斜めにそ 


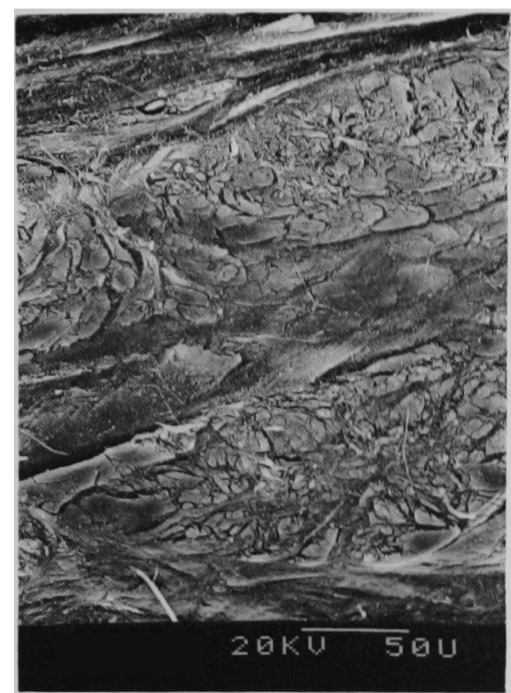

写真 21 円板中央部前類切断厸大像

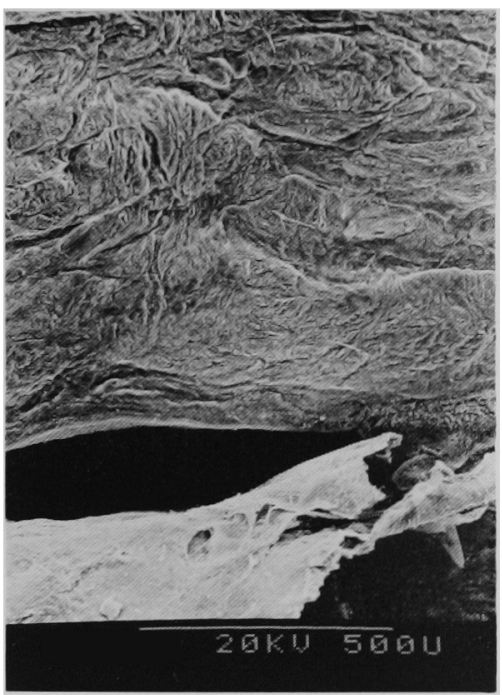

写真 22 円板中央部下層

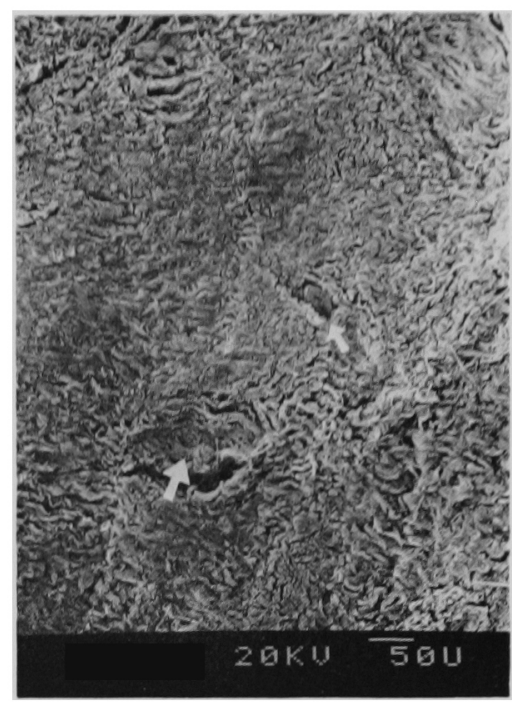

写真 23 円板周丑部 （矢印，血管を示す）

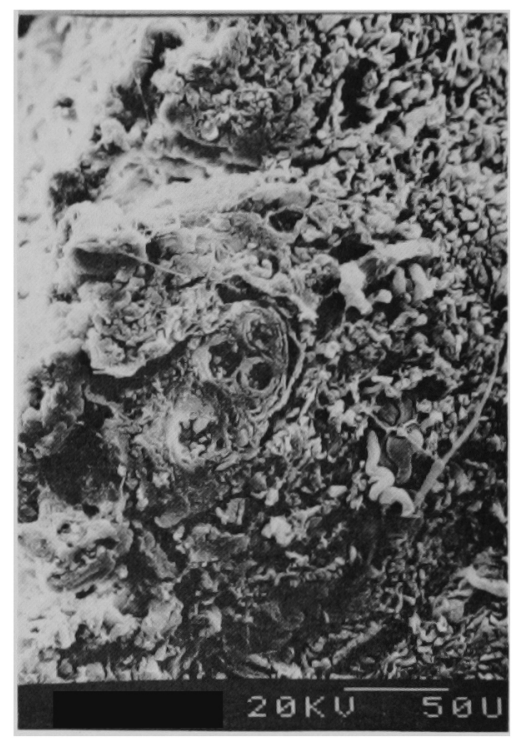

写真 24 写真23扗大像
れぞれ蛇行して走行している。そのため，ざながら毛織 の編み物をみるような構築を呈するが，水平破断面に対 して垂直に走行する線維束は認められない（写真25）.

ii) 後部付近

本部分では，水平破断面に対して垂直に走行する線維 束 (あるいは束群) の断面が多く認められる，前後，内 外側またはそれらに対して斜めになって，それぞれ走行 する線維束 (あるいは束群) と互いに入り組み合い, 線 維構築はきわめて複雑である（写真26）.
考察

\section{1. 試料作製について}

走査電䫒的観察にあたって，まず問題になるのは，㭘 索試料の作製過程に生ずるアーティファクトであるら． 試料作製時のアーティファクトを全く無にすることはで き蒦いが，可及的に少なくすることが必要である。

走査電顕的試料の作製上，もっとも重視されるのは， 


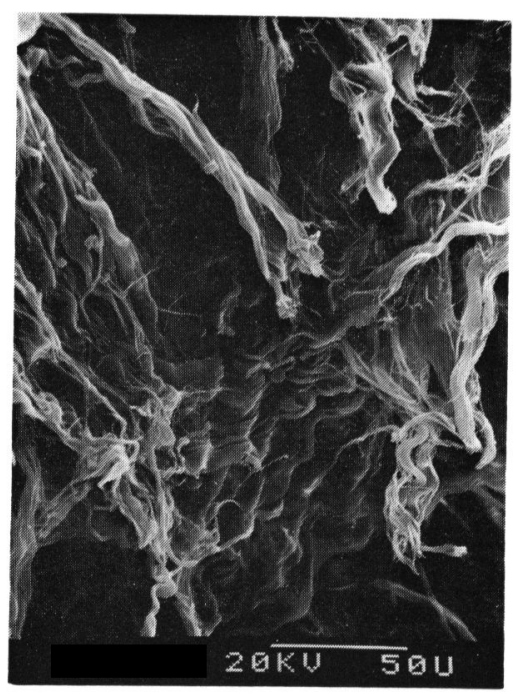

写真 25 円板前部加ら狭窄部移行部付近の水平 破断面像 写真上方が前方，下方が後方，

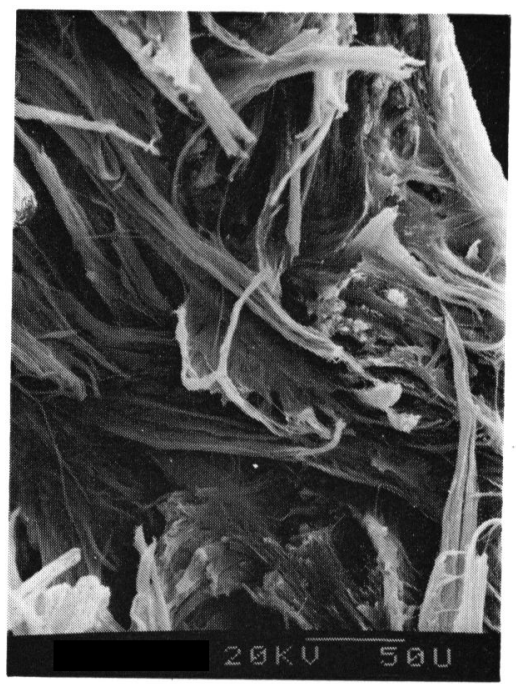

写真 26 円板後部水平破断面像 写真上方が前方，下方が後方。

乾燥過程における試料の収縮であるといわれている。乾 燥法 ${ }^{16)}$ には自然乾燥法 ${ }^{17}$, 凍結乾燥法ならびに臨界点乾 燥法などがあるが，いずれも試料の収縮は避けがたいと いわれる。しかしながら，その中で臨界点乾燥法は，液 体表面に㗢く表面張力を消失させ，大気中での溶媒の気 化に伴ら収縮や凝集を防ぐ利点があるため推奖 ${ }^{16,18)}$ され ている、筆者も本研究にあたっては, 臨界点乾燥法を用 いたが，5 円板の所見をそれぞれ比較して大差のなかっ たことから，試料に大きな影響はなかったものと思って
いる.

走査電顕によって, ヒト円板の線維構築を立体的に掌 握するためには, 断面についても詳しく観察する必要が ある. 凍結破断法によると, 試料の内部構造に変形を与 えないで，その断面が得られるが，ヒト円板のよらに一 定の大きさを有し, 部位によって厚さを異にする硬勒な 線維組織では, 一塊として破断することはきわめて難し い.また，検索したい部位での破断が難しい場合があ る、そのため, 筆者は二こうこ方法をもって円板の断面を 得ることを試みた。まず, 円板断面構造の全琓を把握す るため, グルタールアルデヒドで固定後, 鋭利な両冈型 安全カミソリを用いて ${ }^{19,20)}$, 円板中央で矢状断ならびに 前額断を行った。同法によると平滑な断面が得られ, 線 維構造の全貌がよく鳥瞰されたが, 同法による切断面で は個々の線維束 (あるいは束群) の線維構成や, 切断面 に対して垂直あるいは斜めになって認められる 線維束 （あるいは束群）の走行などを詳しく追跡しがたい点を 見い出した。 そこで筆者は, 前述のカミンリの刃によっ て得られた切断面に隣接する部分から, 大きさ約 $4 \times 3$ $\mathrm{mm}$ 程度の小片を 3 ないし 4 個切り出して凍結固定した のち, 矢状ならびに前額各方向にそれぞれ破断した。そ れらの結果は成績のなかで詳しく述べたと拈りである が，凍結破断法による所見は，力ミソリ法に基づくそれ をよく補足し, 線維束を構成する線維や線維束（あるい は束群）の走行などが，いずれも明暸であった。

上下関節面方向に向かって走行する線維束（あるいは 束群) の存在については, 今までに検討されていない。 それについては, 円板の前部, 狭窄部ならびに後部から それぞれ小片を切り出して, 当初から凍結し, 関節面に 平行に破断（水平破断）して断面を観察した。 その結 果, 上下関節面方向に走行する線維束を前部之後部の中 層に確認したが，とくに後部中層では著明であった。

走査電顕的観察に際して, 円板のような線維性組織の 断面を得るには, 前述したごとく, まずカミソリ法によ る切断を行って構築の全貌を観察し, 線維構成や線維束 の走行などが定かでない場合は, 関連する部分の凍結破 断を行らのがよいと考える。

\section{2. 関節円板の解剖学的区分について}

走査電顕的に円板を観察するにあたって, その領野を あらかじめ決めておくことは, 便宜上必要である。 円板 に拈ける領野の区分については, いまだ一定したものが ない. Bauer ${ }^{3)}$ は肉眼的に中央部と周辺部に, Dixon ${ }^{4}$ は 前部と後部に Choukas \& Sicher ${ }^{5)}$ は円板と後円板床に, $\operatorname{Rees}^{6)}$, Griffin ${ }^{7,8)}$ らは矢状切片を観察して, その厚さの 違いに基ついて前肥厚带 (円板脚部), 中間帯（円板薄 部), 後肥厚带 (円板後部), 二層部に, また本邦では石 橋 ${ }^{9)}$ が前方周縁, 中央, 後方周縁などにそれぞれ区分し ている。

筆者は本研究にあたって, 対象円板を肉眼的に観察 
し，下顎頭ならびに下影窝・网節結節各閔節面に相刘す る円板関節面を，上面からみて，もっとも内汸へくびれ た非海な部分を㢸窄部とし，それを境とし前方の肥原し ている部分を前部，後方を後部と大きく三区分した。

円板の後方にあって，関節包に移行する付近は二凰部

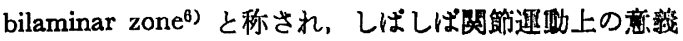

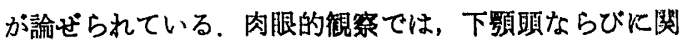
節窞・関節結節各関節顿骨被翲部より外れて括り，夙節 包へ移行する部分に相当し，硬度も㪀かく，裴面にヒダ がみられるなど，本来の円板と考えられる関節面部の性 状とは異にしている，また走查雨顕観察によっても，後 述のごとく，円板後部とは異なり，絬合組䋐の棣相を是 するものであった．したがって篟者は本米の円板とは区 別すべきで，後部結合組織と取り扱う頒取と侤える.

\section{3. 円板前部線維權築について}

光影的観察によると，ヒト円板前部の線維楧築につい ては，扣扣むね，二つの見解に分けることができる，一 つはフェルト状構造説 ${ }^{10)}$, 網状構造説 ${ }^{11)}$, ならびに交錯 状説 ${ }^{12,13)}$ な゙複雑な構造を示すというものであり，他の 一つは，単に前後的な線維の走行である ${ }^{14)}$ とするすので ある.

筆者は走查電顕によって, 円板線維棈筑を検討したと ころ，先人の光顕による所見とは大いに異なる結果を得 た，それについては当然のことながら，根本的に観察方 法を異にするからであるが，走査電顕が光顕に比べて， 焦点深度が樑いため，対象試料の表面に極端な高低がな い限り，試料のすみずみまで焦点が合うので，円板の線 維構築を十分に掌握できたためと思われる.

走查電影によると，円板前部の線維構築は，その違い から，上中下の三層に分けられた，上下両層では，おむ に前後方向に波形をなして走行する線維束（あるいは束 群）からなり，その密な構築は弱払大像で層板状にみえ るが，下層は上層に比べて，より強㗆な印象を受けた。 中層は厚く，前部実質の大部分を占めるもので，線維構 築も上下両層とは全く異なるすのであった。それは特る に前後ならびに斜めに向かって走行する線維束（あるい は束群）からなり，上下方向ならびに内外側方向に走行 する線維束す存在するため，3 次元的とすいえる複雑な 構筑を呈した。 たた後述の後部構築と比べて, 内外側方 向に走行する 線維束が量的に少ないことが 特筆される が，それについては，前後方向への線維束（あるいは束 群）が多いことと考えあわせると，多分に円板前縁に付 着する外側翼突筋上頭の影響を受けているものと思われ る.

\section{4. 円板狭窄部線維構築について}

光影的に観察すると, 狭窄部は一様に矢状方向にはほ 一致し，前後に走行する線維束からなるといわれてい る、筆者も弱拡大像では，一見，矢状方向に前後して走 行する線維束からなるよらにみえたが，強拡大像では，

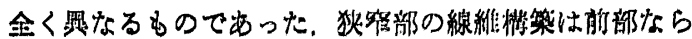

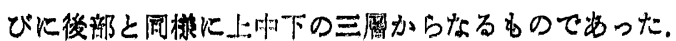

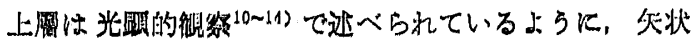

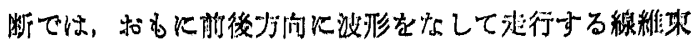

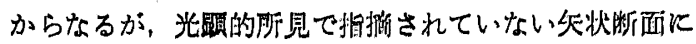

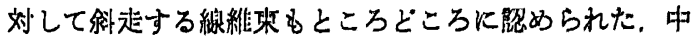

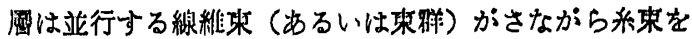
より合わせたよらに互いに入り組み合っており，上周や 後速の下留とは大いに器にするむのであった。一方，下

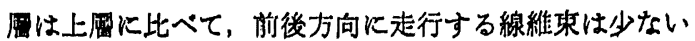
が，反面，矢状断面あるいは円板下面にそれぞれ向かっ

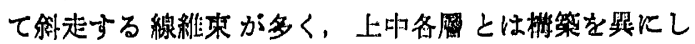
た，このよらな狄窄部下間の線維藓榮は前部ならびに後 部などに特ける下閶に冰めることができないものであっ た，総じて，円板㹨窄部の線維揹築は，前部と後部のそ れと比べて特徵的であるといえる。

円板狭窄部は下䫇頭前縁と関節結節後勾配の両面に介 在する部分であり，下䫑頭可動に際しては，当初から滑 走と蝶番雨運勘に関与する，そのため，同時に伸展と屈 曲を強いられるが，上層の線維榄築は伸展に，下層は屈 曲に，また中層の複雑な構筑は円板の伸展と届曲によっ て生ずる多方向性の張力と㴼に対して，それぞれ対応 したるのと思われる。

\section{5. 円板後部線維粠築について}

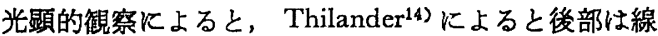
稚の走行から上層と深凰に分けられ，上㬝は前後方向に

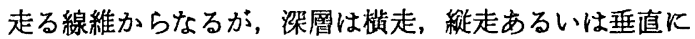
走行する線維からなり, 単に前後的な走行を示す前部と は異にすると述べている. Weinmann \& Sicher ${ }^{10) ら は, ~}$ 後肥厚帯は前肥厚带と同様に 3 次元的であって, フェル 卜状構造を示すと述べているが，それを構成している線 維構築の詳しい記載はない。森永 ${ }^{11)}$, 鈴木 ${ }^{12}$, , 井原 ${ }^{13)}$ ら むWeinmann \& Sicher ${ }^{10}$ らとほぼ同様の結果を報告 している.

簕者の走查電顕による観察では，円板後部も前部や怢 窄部と同じように，上中下の三尿からなり，諸家らの成 績とは全く異にするすのであった，線維構築は基本的に 前部のそれと類似していたが，むしろ密で強勒な棈筑を 呈した. とくに中層は, 前部のそれに比へてい外側方向 に走行する線維束 (あるいは束群) が多く, 前後方向あ るいは上下方向に垂直に走行する線維束（または束群） と複雑に交錯しあって，きわめて複雑な 3 次元的構筑を 呈した。

このような線維構築は，関節可動時に同領域に加わる 多方向性の張力と変形に刘応したものではないかと思わ れる。

今回，筆者はヒト円板の線維棈築を前部，狭窄部なら びに後部に三区分して観察したが，基本的には多少の類 似性を認めたものの，それぞれの領野を構成している線 


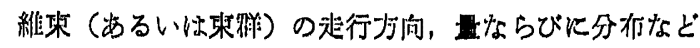
は少しずつ與にしていた，それぞれの部位で嘰能上の役

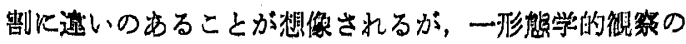

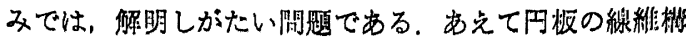
策を総括して洘察を試みるならば，それは成節可㽖時の 倨力と変形に刘処すべく槛成されているものと思われ る.

\section{6. 円板後部結合組織について}

円板後部絬合組維は Rees $\left.{ }^{\theta}\right)$ のいわる Bilaminar zone

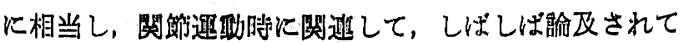
いる. Rees ${ }^{6}$, Griffin \& Sharpe ${ }^{7)}$ らによると組䋐学的 には線維の拝行から二㬝に区分することができるとい れている，籍者の走查能顕的微察によると，円板後部之 明らかに区別しがたく，泪次，移行がみられ，後方に及 ぶに従って線維束は周辺に向かって一様に走行し，し だいに蹯となって血管の出現をみるものであった，後 部結合組織は円板から徐々に関節包へ移行し，付曾する 部分であり，関節可動に際しては，もっとも伸展性の要 求されるところである，筆者が走查電顕で得た棈築はそ れに対応したものであることをよく示していると思われ る.

\section{結語}

走查電子顕微鏡によって，正常ヒト䪽関節円板の関節 面ならびに断面各表面構造を観察し，次の結果を得た。

1. 研究試料はヒト䝷関節円板 (以下, 円板と畵く) 5 例 5 円板であった。 そのうち 4 例 4 円板は，下䝷骨腫 癔症例の下頭関節離断術を施行したおりに，また 1 例 1 円板は舌腫洦症例の剖検時にそれぞれ採取したものであ った.

2. 走查電子顕微鏡的観察を容易にするため, 円板を その肉眼的珄状から，前部，狭窄部ならびに後部に三区 分した。

3. 試料は, すへてて $2.5 \%$ グルタールアルデヒド溶液 (0.1 M リン酸緩衝液， $\mathrm{pH} 7.4)$ で前固定したのち，1 \%四酸化オスミウム溶液 (0.1 M リン酸緩衝液, $\mathrm{pH} 7.4$ ) による後固定を行った.

4. 円板断面は前固定後両刃型安全カミンリによる切 断と凍結固定後の破断によっておのおの作製した。

5. 円板上下両関節面には, その周縁に沿って走行す る幅約 5〜12 $\mu \mathrm{m}$ のヒダ状構造が認められた.

6. 円板の断面構築は, 前部, 狭鿽部ならびに後部の いかんにかかわらず，その上面から下面に及ぶにしたが って異にし，上中下の三層に分けることができた.

7. 円板前部線維構築について, その上層は, おもに 前後方向に波形をなして走行する 線維束（あるいは束 群）からなるものであった，中層は，円板実質の大部分 を占め，扣もに前後ならびに斜めに走行する線維束（あ
るいは束样) からなるが，上下ならびに外僛へ向か， て起行する線維束（あるいは来群）あ存在するため，原

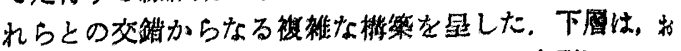
あに前後为问に走行する線維果（あるいは束群）からな り，とくに線維束皏を楼成している線維来の数は上下 比へて少ないが，その交錯はより然であった。

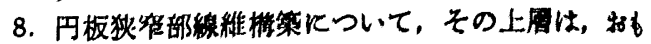
に前後方向に走行する線維来（あるいは来群）からなる

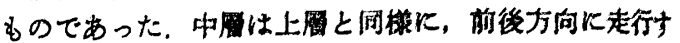
る線維棵 (あるいは束群) を主とするが，並列する維维 果（あるいは東群）は互いに入り租んで括り，さながら 米果をより合わせたような像を呈した，下周は矢状断面 あるいは下面に娰して, やや科めに向かって走行する線

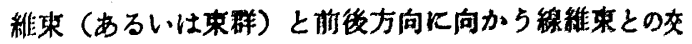

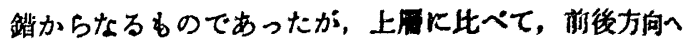
の線稚束は少なかった。

9. 円板後部線維模案について，その上周は，46K

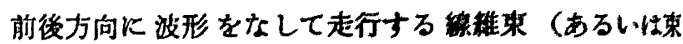
群)からなるすのであった，中雷は，前後，上下ならひ に内外側各方向へ走行する線﨎束（あるいは束群）の交

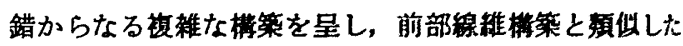
が，内外側一向かって走行する線㱷束 (あるい俚束群)

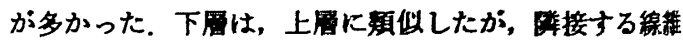
束 (あるいは束群) との入り組みはより著明であった。

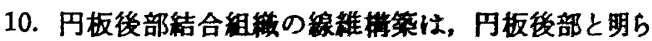

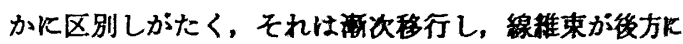
向かって波形をなして走行していた，とくに成節包移行 部付近では線㱷束は悚になり，ところどころに血管る詔 められた。

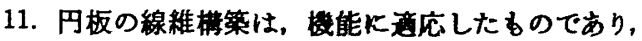
とくに関節可動時に円板に加わる多方向性の張力と变形 に対するすのと思われる。

本諭交の要旨は，第23回日本口腔外科学会综会（昭和 53年 9 月 15 日, 岩手), 第 33 回日本口图科学会飒会 (昭 和54年 4 月 5 日，東京）において発表した。

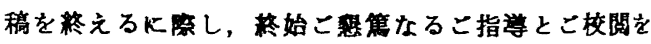
睗った高久遇教授ならびにこ呚閶を睗った本学第2 解剖

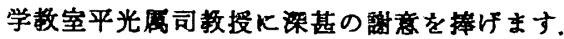

また，種々こ助力をいただいた中央䉓子影微鏡公中村 裕昭請師ならびに村井則子助手に克心より深謝するとと もに，口腔外科学教室各位のこ協力に対し謝意を表しま †.

\section{引用文 献}

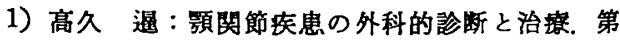
1 版, 書林, 東京, 53頁.

2）高久 遏，小沢重雄：走査電子顕微鏡による七 


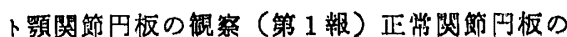

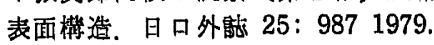

3) Bauer, W.: Anatomische und mikroskopische Untersuchungen über das kiefergelenk mit besonderer Berücksicntigung der Veränderungen bei Osteo-Arthritis deformans. Z Stomat 30: 11361930.

4) Dixon, A.D.: Structure and functional significance of the intra-articular disc of human temporomandibular joint. Oral Surg 15: 48 1962.

5) Choukas, N.C. and Sicher, H.: The structure of the temporomandibular joint. Oral Surg 13: 12031960.

6) Rees, L.A.: The structure and function of the mandibular joint. Brit Dent J 16: 125 1954.

7) Griffin, C.J. and Sharpe, C.J.: The structure of the adult human temporomandibular meniscus. Aust Dent J 5: 1901960.

8) Griffin, C.J. and Sharpe, C.J.: Distribution of elastic tissue in the human temporomandibular meniscus especially in respect to "compression" areas. Aust Dent J 7: 721962.

9) 石橋利文 : 頢関節の構造に関する顕微解剖学的 研究。菌基礎訰 14：201 1972.

10) Weinmann \& Sicher (Sicher, H. and Sarnat, B.G.): The temporomandibular joint. ed 2, Thomas, Springfield Illinois, 1964, p 71.

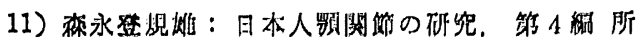

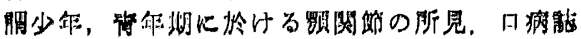

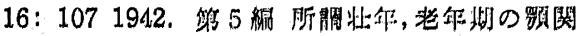

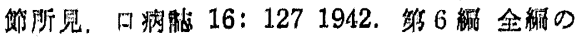

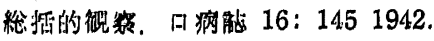

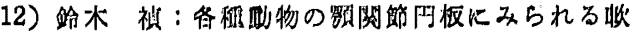

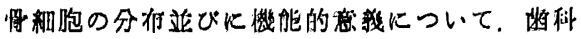
学報 71: 1311.

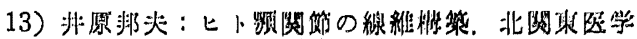
31: 11981.

14) Thilander, B.: Structure of collagen of the temporomandibular joint disc in man. Acta odont scand 22: 1351964.

15) Shapiro, H.H. and Rogers, W.H.: Anatomy of the temporomandibular articulation. Arch Clin Oral Path 3: 51953.

16) 日本電子顕微鏡学会関東支部編：走査電子顕微 唋——基整と応用—. 初版, 共立出版, 東京, 1977, 93頁.

17）徳永純一，他：走查電子顕微鏡に上る表面解剖 アトラス。第一版，医学篦院，東京，1970，3 頁.

18）大隅正子：臨界点乾煤法。細胞 7：99 1975.

19）安井一夫：正常憷関節半月板の立体唡細構造に 関する研究。日整会誌 52：391 1978.

20）非上一：整形外科湎域に打ける Scanning Electron Microscopy の応用, II メニスカス. 臨整外 8: 3341973. 